\title{
OCCUPATIONAL EXPOSURES TO BODY FLUIDS AND BEHAVIORS REGARDING THEIR PREVENTION AND POST-EXPOSURE AMONG MEDICAL AND NURSING STUDENTS AT A BRAZILIAN PUBLIC UNIVERSITY
}

\author{
Fernanda Ribeiro Fagundes de SOUZA-BORGES(1), Larissa Araújo RIBEIRO(2) \& Luiz Carlos Marques de OLIVEIRA(1,3)
}

\begin{abstract}
SUMMARY
A cross-sectional study was conducted to assess the frequencies and characteristics of occupational exposures among medical and nursing students at a Brazilian public university, in addition to their prevention and post-exposure behavior. During the second semester of 2010, a self-administered semi-structured questionnaire was completed by $253 / 320(79.1 \%)$ medical students of the clinical course and 149/200 (74.5\%) nursing students who were already performing practical activities. Among medical students, 53 (20.9\%) suffered 73 injuries, which mainly occurred while performing extra-curricular activities (32.9\%), with cutting and piercing objects (56.2\%), in the emergency room (39.7\%), and as a result of lack of technical preparation or distraction (54.8\%). Among nursing students, 27 (18.1\%) suffered 37 injuries, which mainly occurred with hollow needles $(67.6 \%)$ in the operating room or wards (72.2\%), and as a result of lack of technical preparation or distraction (62.1\%). Among medical and nursing students, respectively, $96.4 \%$ and $48 \%$ were dissatisfied with the instructions on previously received exposure prevention; $48 \%$ and $18 \%$ did not always use personal protective equipment; $67.6 \%$ and $16.8 \%$ recapped used needles; $49.3 \%$ and $35.1 \%$ did not bother to find out the source patient's serological results post-exposure; and $1.4 \%$ and $18.9 \%$ officially reported injuries. In conclusion, this study found high frequencies of exposures among the assessed students, inadequate practices in prevention and post-exposure, and, consequently, the need for training in "standard precautions" to prevent such exposures.
\end{abstract}

KEYWORDS: Occupational exposure; Medical students; Nursing students; Needlestick injuries; Sharp injuries.

\section{INTRODUCTION}

While performing their activities, healthcare workers (HCWs) are at risk of occupational exposures, which can be caused by needle stick injuries (NSIs), sharp object injuries and body fluids being in contact with mucous membranes or non-intact skin. In the United States, it is estimated that 503,000 cutting and piercing injuries (385,000 of which were in hospitals) and 146,000 mucocutaneous exposures occurred among HCWs in $2000^{21}$. In addition, among these professionals, it is estimated that 100,000 sharp injuries (SIs) occur in the United Kingdom ${ }^{39}$ and 500,000 NSIs occur in Germany hospitals ${ }^{28}$ every year, where nearly $160 \mathrm{HCW}$ s retire annually as a result of infections acquired through occupational transmission ${ }^{8}$. However, it is estimated that more than $90 \%$ of occupational exposures which occur worldwide occur in developing countries ${ }^{49}$.

Approximately 60 pathogens can be transmitted through occupational exposures, including viruses, bacteria, parasites and yeasts, and hepatitis $\mathrm{B}(\mathrm{HBV})$, hepatitis $\mathrm{C}$ (HCV) and human immunodeficiency (HIV) viruses account for the majority of cases worldwide ${ }^{38}$. After parenteral exposure with a contaminated needle or sharp object infected with HIV, HCV or $\mathrm{HBV}$, the risk of infection is $0.3 \%, 1.8 \%$ and approximately $30 \%$, respectively, among susceptible individuals ${ }^{5}$. It was estimated that, as a result of occupational exposures, 16,000 HCV infections, 66,000 HBV infections and 1,000 HIV infections occurred worldwide in $2000^{23}$. Due to the risk of acquiring infections that can be transmitted by body fluids, the occupational exposures can result in social stigmas ${ }^{30}$, in addition to psychological stress, with negative repercussions on family, social and professional relationships.

Medical and nursing students develop their skills by performing procedures in which they need to handle cutting and piercing objects with possible accidental contact with body fluids. In some studies, it was reported that medical ${ }^{28}$ and nursing students ${ }^{47}$ have higher risks of suffering occupational exposures than graduate professionals. There are several factors that can contribute to this greater vulnerability among students, such as lack of experience, skills or knowledge about how to handle certain instruments; anxiety; tiredness; lack of tutorial support; lack of care of oneself or other professionals, among others ${ }^{24,25,27,30}$.

The frequencies of the occupational exposures among medical

(1) Postgraduate Program in Health Sciences of the Federal University of Uberlândia Medical School (FAMED/UFU). Uberlândia, MG, Brazil.

(2) Undergraduate medical student of the FAMED/UFU. Uberlândia, MG, Brazil.

(3) Associate professor of the Department of Internal Medicine, FAMED/UFU. Uberlândia, MG, Brazil.

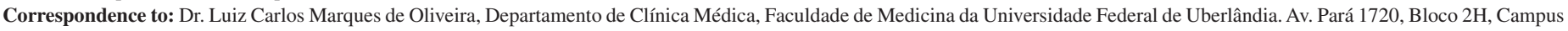
Umuarama, 38405-320 Uberlândia, MG, Brasil. Phone/fax: +55.34.3218-2246. E-mail: oliveiralcm@ufu.br 


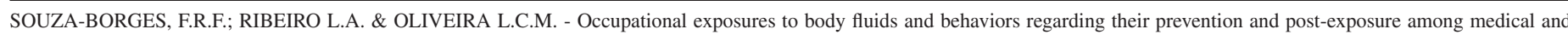
nursing students at a Brazilian public university. Rev. Inst. Med. Trop. Sao Paulo, 56(2): 157-63, 2014.

and nursing students described in several studies vary according to the geographical area of the world where the study was conducted and according to the methodology used during data collection. Some studies took into consideration all injuries occurring among clinical course students, whereas others only considered the injuries that occurred in the last year or last semester of the undergraduate course or only those that had been officially reported. Additionally, certain studies took into consideration only NSIs and/or SIs. Thus, frequencies of occupational exposures varied between $11 \%$ and $74.4 \%$ among medical students $1,6,8,15,16,20,26-29,31,42,43,45$ and between $8.8 \%$ and $61.5 \%$ among nursing students $7,10,32,34,37,41,46,47,49$.

In Brazil, there are few studies that assess the frequencies and characteristics of occupational exposures among medical ${ }^{24}$ and nursing students ${ }^{3,17,25}$; in some studies, the officially reported exposures were evaluated ${ }^{33,35}$. Knowing the characteristics of such injuries can contribute to the implementation of strategies for their prevention. The present study aimed to assess the following among medical and nursing students of a Brazilian public university: 1) the frequencies of occupational exposures; 2) some characteristics of these exposures and the post-exposure actions taken 3 ) whether the students had received appropriate orientation about their behavior in relation to the prevention of such exposures; and 4) whether they had knowledge about the major risks involved in these exposures and the post-exposure actions to be taken.

\section{MATERIALS AND METHODS}

Setting: This cross-sectional study was performed at the end of the second semester of 2010, in the Faculdade de Medicina da Universidade Federal de Uberlândia (FAMED/UFU), in the city of Uberlândia, state of Minas Gerais, Southeastern Brazil. The FAMED/UFU offers three courses: medicine, nursing and nutrition. The curriculum of the undergraduate medical course is comprised of 12 semesters, the first four of which are pre-clinical and the other eight are clinical. The internship corresponds to the period between the $10^{\text {th }}$ and $12^{\text {th }}$ semesters. Medical students can also participate in extracurricular training programs, which are recognized by the FAMED/UFU and where practical activities are developed. The curriculum of the undergraduate nursing course was comprised of eight semesters at the time of data collection; in the following year, two more semesters were included. From the $4^{\text {th }}$ semester on, nursing students perform practical activities, and the period between the $6^{\text {th }}$ and $8^{\text {th }}$ semesters corresponded to the curricular training program, which mainly included practical activities. Medical and nursing students enrolled in the course semesters, described in the present study, perform practical activities in the different levels of the Health Care Network, including the Clinical Hospital of the Federal University of Uberlândia (HC-UFU in the Portuguese acronym).

Subjects and data collection: During the second semester of 2010, there were 320 undergraduate medical students enrolled in the clinical period of their course and 200 nursing students enrolled in the $4^{\text {th }}$ semester or higher, and all of them were invited to participate in this study. During these periods, medical and nursing students are susceptible to the occurrence of occupational exposures, as they participate in practical activities where they handle cutting and piercing objects or where they may be in contact with body fluids. Students were approached in classrooms or at the HC-UFU, between activities.
First, the study objectives were explained and participants' anonymity was guaranteed. Next, a self-administered semi-structured questionnaire was given to each student, including 26 questions to collect sociodemographic data (sex, age, course, semester of enrollment) and several characteristics of possible occupational exposures. The students were asked to report any occupational exposure that had occurred since the beginning of their course. With regard to potentially contaminating injuries, the following data was collected: their frequencies, the material involved (cutting and/or piercing injuries with used hollow needles, suture needles or sharp material, or body fluids being in contact with mucous membranes), affected body area, whether the student was performing or assisting the procedure, hospital site where the injury occurred, frequency of use of personal protective equipment (PPE) and whether there was tutorial support at the moment of exposure.

In addition, data were collected about the reasons attributed to the occurrence of exposures, and on the actions taken after the exposure, such as informing a preceptor and reporting to the Specialized Safety Engineering and Occupational Medicine Service of the HC-UFU (SESMT in the Portuguese acronym). Also, they were asked whether post-exposure the student's and patient's serological tests for HBV, HCV and HIV were performed, whether the students bothered to find out the results of such tests, whether the tests of any source patient was positive for some of these viruses (yes or no), and whether chemoprophylaxis was necessary.

All the students were also asked whether previous instructions on occupational exposure prevention had been satisfactorily received, in addition to instructions on how to act in case of any exposure, what viruses can be transmitted through such injuries and the actions to be taken in case of contact with body fluids from patients infected with these viruses. With regard to knowledge about actions to be taken after biological exposure, knowledge about reporting the injury, about the need for the patient's and student's serological tests, and about the possible need for chemoprophylaxis was taken into consideration.

Data analysis: The information collected was tabulated and stored in the database of the Software Statistical Package for Social Sciences (SPSS version 17.0, IBM Inc., Chicago, IL, USA, 2008). A descriptive analysis was performed for all study variables and the odds ratio with its $95 \%$ confidence interval was calculated to compare the frequency of exposures between sexes. $p$-values $<0.05$ were considered to be significant.

Ethical issues: The present research project was approved by the Institutional Human Research Ethics Committee, official expert opinion 330/10, and a written consent was obtained from each student participating in this study.

\section{RESULTS}

Medical students: A total of 253/320 (79.1\%) medical students participated in the present study, of which $104(41.1 \%)$ were males and $149(58.9 \%)$ were females, with a mean age (standard deviation) of $23.4 \pm 3.1$ years ( 19 to 35 years). Among the 253 medical students, $53(20.9 \%)$ suffered 73 biological exposures, i.e. 35 suffered one injury each, 16 suffered two injuries, and two suffered three injuries. Among students enrolled in each academic semester, the following reported at least one exposure: $0 / 28$ students of the $5^{\text {th }}$ semester, $0 / 29$ students of the 


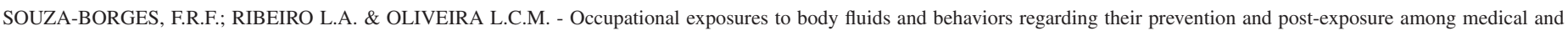
nursing students at a Brazilian public university. Rev. Inst. Med. Trop. Sao Paulo, 56(2): 157-63, 2014.

$6^{\text {th }}$ semester, $2 / 30(6.7 \%)$ students of the $7^{\text {th }}$ semester, $5 / 34(14.7 \%)$ of the $8^{\text {th }}$ semester, $13 / 39(33.3 \%)$ of the $9^{\text {th }}$ semester, $10 / 30(33.3 \%)$ of the $10^{\text {th }}$ semester, $13 / 33(39.4 \%)$ of the $11^{\text {th }}$ semester, and $10 / 30(33.3 \%)$ of the $12^{\text {th }}$ semester. The frequencies of such injuries were similar $(\mathrm{OR}=1.0$; $95 \%$ CI 0.6 to 1.9$)$ among men [22 (21.2\%)] and women [31 (20.8\%)]. The frequencies of injuries according to academic semester of occurrence are shown in Table 1. The frequencies of cutting and/or piercing injuries and of body fluids being in contact with mucous membranes, the hospital sites of occurrence and the reasons attributed to the occurrence of exposures are listed in Table 2.

Table 1

Frequency of occupational exposures among medical $(\mathrm{N}=73)$ and nursing $(\mathrm{N}=37)$ students according to academic semester of occurrence

\begin{tabular}{lcccc}
\hline \multirow{2}{*}{$\begin{array}{l}\text { Semester of } \\
\text { occurrence }\end{array}$} & \multicolumn{4}{c}{ Occupational exposures } \\
\cline { 2 - 5 } & \multicolumn{2}{c}{ Medical students } & Nursing students \\
\hline$n^{\text {th }}$ & $\mathrm{N}$ & $\%$ & $\mathrm{~N}$ & $\%$ \\
$5^{\text {th }}$ & 1 & 1.4 & 10 & 27.0 \\
$6^{\text {th }}$ & 4 & 5.5 & 8 & 21.6 \\
$7^{\text {th }}$ & 24 & 32.9 & 2 & 5.4 \\
$8^{\text {th }}$ & 9 & 12.3 & 3 & 8.1 \\
$9^{\text {th }}$ & 3 & 4.1 & NA & \\
$10^{\text {th }}$ & 19 & 26.0 & NA & \\
$11^{\text {th }}$ & 12 & 16.4 & NA & \\
$12^{\text {th }}$ & 1 & 1.4 & NA & \\
Others $^{\text {a }}$ & 0 & & 8 & 21.6 \\
\hline Total & 73 & 100 & 37 & 100 \\
\hline
\end{tabular}

$\mathrm{N}(\%)$ : number and percentage. ${ }^{\mathrm{a}}$ Three $(8.1 \%)$ injuries occurred in the $1^{\mathrm{st}}$ semester and five $(13.5 \%)$ in the $3^{\text {rd }}$ semester. NA $=$ not applicable.

Occupational exposures occurred more frequently while students performed procedures [62 (84.9\%)] than while they assisted/observed procedures [11 (15.1\%)]; additionally, these injuries were more frequent when students had tutorial support [46 (63\%) vs. 27 (37\%)]. The body parts affected were the hands [42 (57.5\%)] and the ocular and oral mucous membranes [26 (35.6\%)], whereas five injuries $(6.8 \%)$ were associated with other unspecified parts. Students were not wearing gloves in $8 / 73$ $(11 \%)$ injuries.

A total of 55 injuries $(75.3 \%)$ were reported to a preceptor and one (1.4\%) was also reported to the SESMT. In 12 out of the $18(24.7 \%)$ exposures that were not reported to the preceptor or SESMT, students informed the reasons for not reporting: little or no perception of risk [6 (50\%)], belief that it was not necessary [4 (33.3\%)], fear and embarrassment [1 $(8.3 \%)$, and lack of orientation about reporting [1 $(8.3 \%)]$; this information could not be obtained from four exposures. Students had post-exposure serological tests in $36(49.3 \%)$ injuries. Among the 73 source patients, four $(5.5 \%)$ had positive serological tests for HBV, HCV or HIV, 33 (45.2\%) had negative serological tests for these viruses, and students were not concerned about the results of the
Table 2

Frequency of occupational exposures among medical $(\mathrm{N}=73)$ and nursing $(\mathrm{N}=37)$ students according to type of injury, site of occurrence and reasons attributed to the occurrence of exposures

\begin{tabular}{lcccc}
\hline \multirow{2}{*}{ Variables } & \multicolumn{4}{c}{ Occupational exposures } \\
\cline { 2 - 5 } & \multicolumn{2}{c}{$\begin{array}{c}\text { Medical } \\
\text { students }\end{array}$} & \multicolumn{2}{c}{$\begin{array}{c}\text { Nursing } \\
\text { students }\end{array}$} \\
\cline { 2 - 5 } & $\mathrm{N}$ & $\%$ & $\mathrm{~N}$ & $\%$ \\
\hline Cutting and piercing injuries & 41 & 56.2 & 27 & 73.0 \\
Suture needles & 25 & 34.2 & 0 & \\
Hollow needles & 10 & 13.7 & 25 & 67.6 \\
Blades & 6 & 8.2 & 2 & 5.4 \\
Body fluids & 32 & 43.8 & 10 & 27.0 \\
Blood & 26 & 35.6 & 4 & 10.8 \\
Others & $6^{\mathrm{a}}$ & 8.2 & $6^{\mathrm{b}}$ & 16.2 \\
Site of occurrence & & & & \\
Emergency room & & & & \\
Operating room & 29 & 39.7 & 2 & 5.6 \\
Obstetric center & 23 & 31.5 & 10 & 27.8 \\
Medical clinic ward & 13 & 17.8 & 0 & \\
Pediatric clinic ward & 1 & 1.4 & 9 & 25.0 \\
Others & 1 & 1.4 & 7 & 19.4 \\
Reason for exposure & 9 & 12.3 & 6 & 16.2 \\
Lack of technical preparation & 20 & 27.4 & 7 & 18.9 \\
Distraction & 20 & 27.4 & 16 & 43.2 \\
Tiredness & $6^{\mathrm{d}}$ & 8.2 & $8^{\mathrm{e}}$ & 22.2 \\
Lack of tutorial support & & & & \\
Lack of PPE & 5 & 6.8 & 2 & 5.4 \\
Lack of care from others & 4 & 5.5 & 0 & \\
Others & & 13.7 & $6^{\mathrm{h}}$ & 16.2 \\
\hline
\end{tabular}

${ }^{a}$ Nasal secretion $(\mathrm{n}=1)$, amniotic liquid $(\mathrm{n}=1)$, synovial liquid $(\mathrm{n}=1)$, not informed $(n=3)$. ${ }^{b}$ nasal secretion $(n=4)$, not informed $(n=2) .{ }^{c}$ percentages calculated considering the valid responses. ${ }^{\mathrm{d}}$ outpatient surgery $(\mathrm{n}=4)$, meeting room $(n=1)$, maternity ward $(n=1) .{ }^{e}$ Intensive care unit $(n=4)$; blood bank $(\mathrm{n}=1)$; infectious diseases ward $(\mathrm{n}=1)$, vaccination $(\mathrm{n}=1)$, maternity ward $(\mathrm{n}=1),{ }^{\mathrm{f}}$ student could choose more than one alternative. ${ }^{\mathrm{g}}$ patient movements $(\mathrm{n}=2)$; defects in the equipment $(\mathrm{n}=1)$; not specified $(\mathrm{n}=7) .{ }^{\mathrm{h}}$ nervousness $(\mathrm{n}=1)$; haste $(\mathrm{n}=1)$; peer pressure $(\mathrm{n}=1)$; not specified $(\mathrm{n}=3)$.

patients' tests in 36 (49.3\%) exposures. Additionally, students underwent chemoprophylaxis in $2 / 73(2.7 \%)$ exposures.

Among medical students who participated in this study, nine (3.6\%) said that they had satisfactorily received previous instructions on biological exposure prevention, 56 (22.1\%) considered these instructions to be insufficient, and $188(74.3 \%)$ said that they had not received any instructions. Recapping used needles was performed by $156(61.7 \%)$ students, 15 (5.9\%) reported that they recapped used needles with one 


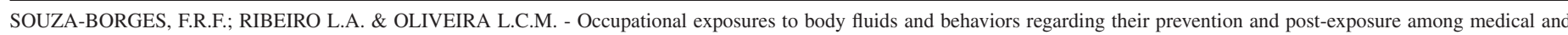
nursing students at a Brazilian public university. Rev. Inst. Med. Trop. Sao Paulo, 56(2): 157-63, 2014.

hand and using a protective shield and $82(32.4 \%)$ said that they did not do this. Among 236/253 (93.3\%) students who gave information on the use of PPE, $123(52.1 \%)$ reported that they always used PPE, 108 (45.8\%) used it sporadically, and five $(2.1 \%)$ never used it.

When asked about what viruses could be transmitted through occupational exposures, 202 (79.8\%) students mentioned the HCV; 206 (81.4\%), the HBV; 217 (85.8\%), the HIV; and 36 (14.2\%) did not mention any viruses. The actions to be taken after any biological exposures were unknown or partially known by $212(83.8 \%)$ medical students. The actions to be taken after being exposed to body fluids from infected patients were unknown or partially known by 246 (97.2\%) students.

Nursing students: A total of 149/200 (74.5\%) nursing students participated in this study, of which $22(14.8 \%)$ were males and 127 $(85.2 \%)$ were females, with a mean age of $22.1 \pm 3.7$ years (18 to 42 years). Among the 149 nursing students, 27 (18.1\%) suffered 37 occupational exposures, i.e. 19 students suffered one injury each, six suffered two injuries, and two suffered three injuries. Among students enrolled in each academic semester, the following reported at least one exposure: $5 / 31(16.1 \%)$ students enrolled in the $4^{\text {th }}$ semester; $1 / 31(3.2 \%)$ in the fifth semester; $7 / 29(24.1 \%)$ in the $6^{\text {th }}$ semester; $4 / 28(14.3 \%)$ in the $7^{\text {th }}$ semester; and $10 / 30(33.3 \%)$ in the $8^{\text {th }}$ semester. The frequencies of occupational exposures were similar $(\mathrm{OR}=1.5$; 95\% CI 0.4 a 5.4$)$ among men [3 (13.6\%)] and women [24 (18.9\%)]. The frequencies of injuries according to the academic semester of occurrences are shown in Table 1. The frequencies of cutting and piercing injuries and of body fluids being in contact with mucous membranes, the hospital sites of occurrence and the reasons for such occurrences are listed in Table 2.

Occupational exposures occurred more frequently while students performed procedures $[30(81.1 \%)]$ than while they assisted/observed procedures [7 (18.9\%)]; additionally, exposures were more frequent when there was tutorial support [23 (62.2\%) vs. $14(37.8 \%)]$. The body parts affected were the hands $[29 / 36(80.6 \%)]$ and ocular and oral mucous membranes [7/36 (19.4\%)]; one student did not give this information. Students were not wearing gloves in 5/37 (13.5\%) injuries.

A total of 25 injuries $(67.6 \%)$ were reported to a preceptor and seven $(18.9 \%)$ were also reported to the SESMT. In eight out of the $12(32.4 \%)$ exposures that were not reported to the preceptor or SESMT, students informed the reasons for not reporting: negligence [3 $(37.5 \%)]$, little or no perception of risk [1 (12.5\%)], belief that it was not necessary [1 (12.5\%)], fear of warnings [1 (12.5\%)], embarrassment [1 (12.5\%)], and unwillingness to report [1 (12.5\%)]; this information could not be obtained from four exposures. Students had post-exposure serological tests in $16(43.2 \%)$ injuries. Among the 37 source patients, three $(8.1 \%)$ had positive serological tests for HBV, HCV or HIV, 21 $(56.8 \%)$ had negative serological tests for these viruses, and students were not concerned about the results of the patients' tests in $13(35.1 \%)$ exposures. Additionally, students underwent chemoprophylaxis in 4/37 $(10.8 \%)$ exposures.

Among nursing students who participated in this study, 78 (52.3\%) said that they had satisfactorily received previous instructions on exposure prevention, whereas $60(40.3 \%)$ considered these instructions to be insufficient, and $11(7.4 \%)$ said that they had not received them. Recapping used needles was performed by 22 (14.8\%) students, three
(2\%) reported that they recapped used needles with one hand and using a protective shield and $124(83.2 \%)$ said that they did not do this. Among $134 / 149(89.9 \%)$ students who gave information on the use of PPE, 110 $(82.1 \%)$ reported that they always used PPE, whereas $24(17.9 \%)$ used it sporadically.

When asked about what viruses could be transmitted through occupational exposures, 99 (66.4\%) students mentioned HCV; 119 (79.9\%), HBV; 127 (85.2\%), HIV; and 21 (14.1\%) did not mention any of them. The actions to be taken after any biological exposure were unknown or partly known by $127(85.2 \%)$ students. The actions to be taken after being exposed to body fluids from infected patients were unknown or partly known by $128(85.9 \%)$ students.

\section{DISCUSSION}

The present study revealed high frequencies of occupational exposures among medical and nursing students. In other studies conducted in Brazil, high frequencies of exposures were also found among medical students of the Federal University of Minas Gerais (34.2\%) ${ }^{24}$ and among nursing students of universities located in the interior of the state of São Paulo $\left(12.4 \%^{3}\right.$ and $\left.40 \%{ }^{25}\right)$. There were no differences in frequencies of exposures between women and men, as observed in Malaysia ${ }^{16}$, in the USA $^{30}$ and in Austria, Germany and the United Kingdom ${ }^{27}$. There was an increase in the number of medical students who reported injuries as the course advanced, as observed in other studies ${ }^{8,24,26}$. This results from the increasing number of procedures that they must perform during their training to acquire the skills required, which leads to a more frequent risk of exposure. However, it should be emphasized that, among medical students, one-third of the injuries occurred in the $7^{\text {th }}$ academic semester. In this semester, there are no disciplines in the medical course that puts students at risk of injuries. However, medical students may take an extracurricular training program where they perform invasive procedures, such as sutures and local anesthesia, and where they can assist major procedures. On the other hand, the low frequency of exposures in the $12^{\text {th }}$ semester results from the fact that medical students only perform outpatient procedures with low risk of exposure in this semester.

Studies conducted in several parts of the world have found an increase in the incidence of injuries among nursing students as the course advances ${ }^{7,34,41,49}$, as a result of the higher frequency of contact with patients and handling of cutting and piercing objects. However, the present study showed a reduction in the occurrence of occupational exposures among nursing students as the course advanced. A similar fact was observed in an Italian study that found that the probability of occupational exposure among nursing students was significantly lower with the increase in clinical skills and in knowledge about exposure prevention and the risks involved with injuries ${ }^{22}$. In addition, it should be emphasized that one-fifth of the exposures involving nursing students occurred in the $1^{\text {st }}$ and $3^{\text {rd }}$ course semesters, which could only take place in extra-curricular activities.

Medical students more frequently suffered injuries with suture needles, whereas nursing students more frequently suffered injuries with hollow needles, as a result of the characteristics of the activities performed by them. In the hospital where the present study was conducted, suture procedures are exclusively performed by physicians or medical students. In other studies conducted in $\mathrm{Brazil}^{24}$ and in the $\mathrm{USA}^{30}$, medical students 


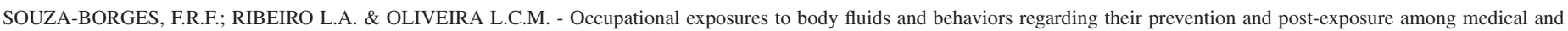
nursing students at a Brazilian public university. Rev. Inst. Med. Trop. Sao Paulo, 56(2): 157-63, 2014

also suffered more frequent injuries with suture needles as well, whereas nursing students were injured mostly by hollow needles ${ }^{37,47}$.

Among medical students, the hospital sites with the highest occurrence of exposures were the emergency room, operating room and obstetric center. In such locations, they have a greater chance of handling cutting and piercing objects, which may contribute to the occurrence of injuries, in addition to their inexperience, anxiety in performing a procedure, rushing, and the patient's suffering and/or pressure. Among nursing students, injuries mainly occurred in the operating room and wards of the medical and pediatric clinics, the three sites where they most frequently develop their skills.

Medical and nursing students reported that lack of technical preparation, distraction and tiredness were the main reasons for the occurrence of exposures, as similarly observed in other studies with medical students ${ }^{24,27,30}$ and nursing students ${ }^{7}$. However, while some students attributed injuries to the lack of tutorial support, paradoxically, these injuries most frequently occurred when there was tutorial support. In these cases, the students' anxiety in performing a procedure associated with feelings of being watched, assessed or hurried could contribute to the occurrence of such injuries. In this study, lack of care from other professionals was the reason attributed by medical students for $5.5 \%$ of exposures, a lower frequency than that found among medical students in Toronto, Canada $(48 \%)^{6}$.

This study showed that many students, especially medical students, have a habit of recapping used needles. Since 1987, when "universal precautions" were published to prevent the transmission of infections through exposures involving body fluids, it was determined that needles should never be recapped, purposely bent or broken, or removed from disposable syringes ${ }^{4}$. Despite these instructions, worldwide, medical students ${ }^{1,9,26,29,36,43}$ and nursing students s,37,47 $^{7}$ frequently recap used needles and many believe that this procedure is safe and reduces the risk of exposures ${ }^{9}$. Recapping needles with one hand while using a protective shield or tweezers is an action performed by several students, although this way of recapping needles does not eliminate the risk of occupational exposure $^{13}$.

Injuries most frequently affected the hands and ocular and oral mucous membranes, as observed in other studies with medical students ${ }^{24,31}$ and nursing students ${ }^{25,41}$. This fact shows the importance of emphasizing the use of gloves, masks and goggles when students are performing or assisting procedures.

Slightly more than two-thirds of exposures were informed to a preceptor and official reports were rarely made. These reports enable the hospital committee to know the reality and thus take action to minimize the occurrence of such exposures. However, despite all biological exposures causing suffering and anguish from the fear of acquiring infections, not reporting exposures is the rule rather than the exception worldwide. Similarly to what was observed in this study, the reasons for medical students ${ }^{15,16,26,28,45}$ and nursing students ${ }^{7,10,32,34,37}$ not reporting injuries are similar, including little or no perception of risk, embarrassment, lack of time, fear of the consequences of reporting (avoidance of the inconvenience of a report and follow-up, the negative effect on their professional career and the stigmatization by other students, residents and professionals), reluctance to admit lack of knowledge about how to handle instruments, not knowing how and where to report, among others.

Many students who suffered injuries were not concerned about finding out the results of patients' serological tests and did not know what viruses can be transmitted through occupational exposure. Additionally, $85 \%$ of them did not know what actions should be taken after any biological exposure. These results show that several students were not aware of the risks to which they were exposed when performing the procedures. Additionally, they reveal the need for greater efforts to teach standard precautions before the beginning of their practical activities.

Exposure prevention among students must be an institutional concern, although every preceptor and student must become aware of their responsibility for this prevention. Some studies revealed that knowledge about "universal precautions" alone is not sufficient to implement safe practices $^{11,19}$. In the present study, based on the information obtained, nursing students seem to receive more and better instructions on occupational exposure prevention than medical students, as observed in South Korea ${ }^{12}$. Medical students reported not receiving instructions on occupational exposure prevention, recapping used needles and not using PPE more frequently than nursing students. However, the frequencies of occupational exposures and not wearing gloves at the time of exposure were similar between medical and nursing students. Students need to receive not only information, but also training for "standard prevention" 22. In a study conducted in Seattle, USA, medical students reported that the teaching on the use of universal precautions was inadequate and that preceptors were poor role models when they ignored these precautions $\mathrm{s}^{40}$. On the other hand, prospective studies with medical students ${ }^{14}$ and nursing students ${ }^{44,48}$ have showed that structured training for occupational exposure prevention improves knowledge and behavior and reduces the number of exposures, in addition to a possible development of a better professional behavior.

Students also need to receive information about the main pathogens that can be transmitted through biological exposure, how to prevent these infections, how to behave in case of exposure, and how to report occupational exposures. A previous study revealed that medical students of the FAMED/UFU had high rates of vaccination against hepatitis $\mathrm{B}^{18}$ and that this vaccine must be made available without cost to all students in the area of health prior to their practical activities. No vaccines against HIV or HCV have been developed until now, however, chemoprophylaxis can be effective against HIV, although it must start in the first hours after exposure ${ }^{2}$.

\section{STUDY LIMITATIONS}

In this cross-sectional study, students were required to remember whether they had suffered occupational exposure or not, in addition to several characteristics of such exposures and, for this reason, memory bias may have occurred. Nonetheless, occupational exposures are stressful events that are not easily forgotten, especially potentially contaminating ones. As the present study was conducted in one university exclusively, the results cannot be extended to the entire country. Further studies should be conducted to find out whether the results of the present study can represent what occurs in other Brazilian universities. Occupational exposures considered to be low risk were not assessed, such as those occurring when uncapping new needles, breaking vials or being injured by unused objects. 
SOUZA-BORGES, F.R.F.; RIBEIRO L.A. \& OLIVEIRA L.C.M. - Occupational exposures to body fluids and behaviors regarding their prevention and post-exposure among medical and nursing students at a Brazilian public university. Rev. Inst. Med. Trop. Sao Paulo, 56(2): 157-63, 2014.

In some studies conducted with nursing students it was observed that accidents of this nature may represent more than $80 \%$ of the total and the injuries caused by them, especially in the hands, can lead to contamination after exposure to biological material ${ }^{25,34}$. Additionally, researchers of this study did not investigate the number of procedures performed by each student, thus hindering the calculation of the risk per procedure.

\section{CONCLUSIONS}

The present study showed high frequencies of potentially contaminating occupational exposures among medical and nursing students. Moreover, there were many reports of insufficient or inexistent instructions on biological exposure prevention. This could justify students' frequent neglect for the use of PPE, the frequent high-risk procedures such as not wearing gloves or recapping used needles, not reporting exposures to official institutions, and the low level of knowledge about post-exposure actions. Additionally, the high frequency of exposures in extra-curricular activities stood out. The results of this study will be sent to the proper authorities of the FAMED/UFU for the continuous development and improvement of strategies to protect students against such exposures.

\section{RESUMO}

\section{Exposições ocupacionais a fluídos corporais e comportamentos em relação à sua prevenção e pós-exposição entre estudantes de medicina e de enfermagem de universidade pública brasileira}

Estudo transversal foi realizado para verificar, entre estudantes de medicina e de enfermagem de universidade pública brasileira, as frequências e características de exposições ocupacionais e seus comportamentos na prevenção e pós-exposição. Durante o segundo semestre de 2010, questionário autoaplicável e semiestruturado foi completado por $253 / 320(79,1 \%)$ estudantes de medicina do curso clínico e por 149/200 (74,5\%) estudantes de enfermagem que já exerciam atividades práticas. Entre os estudantes de medicina, 53 (20,9\%) sofreram 73 acidentes, que ocorreram principalmente em atividades extracurriculares $(32,9 \%)$, com objetos pérfuro-cortantes $(56,2 \%)$, na sala de emergência $(39,7 \%)$ e em decorrência de despreparo técnico ou distração $(54,8 \%)$. Entre os alunos de enfermagem, $27(18,1 \%)$ sofreram 37 acidentes, que ocorreram principalmente com agulhas ocas $(67,6 \%)$, no centro cirúrgico ou enfermarias $(72,2 \%)$ e em decorrência de despreparo técnico ou distração $(62,1 \%)$. Entre os alunos de medicina e de enfermagem, respectivamente, $96,4 \%$ e $48 \%$ estavam insatisfeitos com orientações previamente recebidas de prevenção de acidentes, $48 \%$ e $18 \%$ nem sempre utilizam equipamento de proteção individual, 67,6\% e $16,8 \%$ reencapam agulhas usadas, $49,3 \%$ e $35,1 \%$ não se preocuparam em conhecer os exames sorológicos do paciente-fonte pós-exposição e $1,4 \%$ e $18,9 \%$ relataram o acidente oficialmente. Em conclusão, neste estudo verificaram-se altas frequências de exposições entre os estudantes avaliados, práticas inadequadas na prevenção e pós-exposição e, consequentemente, a necessidade de treinamento nas "precauções padrão" para prevenção de tais exposições.

\section{ACKNOWLEDGEMENTS}

Authors would like to thank all medical students and nursing students who participated in this study.

\section{AUTHORS' CONTRIBUTIONS}

FRFSB participated in the data collection and analysis and manuscript preparation. LAR participated in the study design, data collection and analysis and manuscript preparation. LCMO participated in the study design, data analysis and manuscript preparation. All authors read and approved the final manuscript.

\section{REFERENCES}

1. Al-Dabbas M, Abu-Rmeileh NME. Needlestick injury among interns and medical students in the Occupied Palestinian Territory. East Mediterr Health J. 2012;18:700-6.

2. Brasil. Ministério da Saúde. Secretaria de Estado de Saúde de Minas Gerais. Atendimento ao acidentado com material biológico. 2004. Available from: http:// www.saude.mg.gov.br/politicas_de_saude/dst-aids/encontro-de-referencia-dst_aids/ vi-encontro-de-referencias-em-dst_aids/Protocolo\%20Biosseguranca.pdf

3. Canalli RTC, Moriya TM, Hayashida M. Acidentes com material biológico entre estudantes de enfermagem. Rev Enferm UERJ. 2010;18:259-64.

4. Centers for Disease Control and Prevention. Perspectives in disease prevention and health promotion. Update: universal precautions for prevention of transmission of human immunodeficiency virus, hepatitis B virus, and other bloodborne pathogens in health-care settings. MMWR. 1988;37:377-88.

5. Centers for Disease Control and Prevention. Updated U.S. Public Health Service: guidelines for the management of occupational exposures to $\mathrm{HBV}, \mathrm{HCV}$, and HIV and recommendations for postexposure prophylaxis. U.S. Public Health Service. MMWR Recomm Rep. 2001;50:1-42.

6. Cervini P, Bell C. Brief report: needlestick injury and inadequate post-exposure practice in medical students. J Gen Intern Med. 2005;20:419-21.

7. Cheung K, Ching SSY, Chang KKP, Ho SC. Prevalence of and risk factors for needlestick and sharps injuries among nursing students in Hong Kong. Am J Infect Control. 2012;40:997-1001.

8. Deisenhammer S, Radon K, Nowak D, Reichert J. Needlestick injuries during medical training. J Hosp Infect. 2006;63:263-7.

9. Elliott SKF, Keeton A, Holt A. Medical students' knowledge of sharps injuries. J Hosp Infect. 2005;60:374-7.

10. Irmak Z, Baybuga MS. Needlestick and sharps injuries among Turkish nursing students: a cross-sectional study. Int J Nurs Pract. 2011;17:151-7.

11. Karim J, Al-Saraji M, Al-Mousawi F, Al-Haddad Z, Al-Sharaf D, Marwan Y, et al. Knowledge and self-reported practice of universal precautions among Kuwait university medical students in their clinical years. Med Princ Pract. 2012;21:328-33.

12. Kim KM, Kim MA, Chung YS, Kim NC. Knowledge and performance of the universal precautions by nursing and medical students in Korea. Am J Infect Control. 2001;29:295-300.

13. Marziale MHP, Rodrigues CM. A produção científica sobre os acidentes de trabalho com material perfurocortante entre trabalhadores de enfermagem. Rev Lat Am Enfermagem. 2002;10:571-7.

14. Merlin JS, Morrison G, Gluckman S, Lipschik G, Linkin DR, Lyon S, et al. Blood and body fluid exposures among US medical students in Botswana. J Gen Intern Med. 2011;26:561-4

15. Moon CS, Hwang JH, Lee CS, Park KH, Kim ES. Exposure to blood and body fluid among medical students in Korea. Am J Infect Control. 2010;38:582-3.

16. Norsayani MY, Hassim IN. Study on incidence of needle stick injury and factors associated with this problem among medical students. J Occup Health. 2003;45:172-8. 
SOUZA-BORGES, F.R.F.; RIBEIRO L.A. \& OLIVEIRA L.C.M. - Occupational exposures to body fluids and behaviors regarding their prevention and post-exposure among medical and nursing students at a Brazilian public university. Rev. Inst. Med. Trop. Sao Paulo, 56(2): 157-63, 2014.

17. Oliveira AC, Gonçalves JA. Incidência de acidentes com material perfurocortante entre alunos de graduação em ciências da saúde. Ci Cuid Saude. 2009;8:385-92.

18. Oliveira LCM, Pontes JPJ. Frequency of hepatitis B immunity and occupational exposures to body fluids among Brazilian medical students at a Public University. Rev Inst Med Trop Sao Paulo. 2010;52:247-52.

19. Osborn EHS, Papadakis MA, Gerberding JL. Occupational exposures to body fluids among medical students: a seven-year longitudinal study. Ann Intern Med. $1999 ; 130: 45-51$

20. Patterson JMM, Novak CB, Mackinnon SE, Ellis RA. Needlestick injuries among medical students. Am J Infect Control. 2003;31:226-30.

21. Perry J, Jagger J. Healthcare worker blood exposure risks: correcting some outdated statistics. Adv Exp Prev. 2003;6:28-31

22. Petrucci C, Alvaro R, Cicolini G, Cerone MP, Lancia L. Percutaneous and mucocutaneous exposures in nursing students: an Italian observational study. J Nurs Scholarsh. 2009;41:337-43

23. Prüss-Ustün A, Rapiti E, Hutin Y. Estimation of the global burden of disease attributable to contaminated sharps injuries among health-care workers. Am J Ind Med. 2005;48:482-90.

24. Reis JMB, Lamounier Filho A, Rampinelli CA, Soares ECS, Prado RS, Pedroso ERP. Training-related accidents during teacher-student-assistance activities of medical students. Rev Soc Bras Med Trop. 2004;37:405-8.

25. Reis RK, Gir E, Canini SRMS. Accidents with biological material among undergraduate nursing students in a public Brazilian university. Braz J Infect Dis. 2004;8:18-24.

26. Rosenthal E, Pradier C, Keita-Perse O, Altare J, Dellamonica P, Cassuto JP. Needlestick injuries among French medical students. JAMA. 1999;281:1660.

27. Salzer HJF, Hoenigl M, Kessler HH, Stigler FL, Raggam RB, Rippel KE, et al. Lack of risk-awareness and reporting behavior towards HIV infection through needlestick injury among European medical students. Int J Hyg Environ Health. 2011;214:407-10.

28. Schmid K, Schwager C, Drexler H. Needlestick injuries and other occupational exposures to body fluids amongst employees and medical students of a German university: incidence and follow-up. J Hosp Infect. 2007;65:124-30.

29. Shariati B, Shahidzadeh-Mahani A, Oveysi T, Akhlaghi H. Accidental exposure to blood in medical interns of Tehran University of Medical Sciences. J Occup Health. 2007;49:317-21

30. Sharma GK, Gilson MM, Nathan H, Makary MA. Needlestick injuries among medical students: incidence and implications. Acad Med. 2009;84:1815-21.

31. Shen C, Jagger J, Pearson RD. Risk of needle stick and sharp object injuries among medical students. Am J Infect Control. 1999;27:435-7.

32. Shiao JSC, McLaws ML, Huang KY, Guo YL. Student nurses in Taiwan at high risk for needlestick injuries. Ann Epidemiol. 2002;12:197-201.

33. Shimizu HE, Ribeiro EJG. Ocorrência de acidente de trabalho por materiais perfurocortantes e fluídos biológicos em estudantes e trabalhadores da saúde de um hospital escola de Brasília. Rev Esc Enferm USP. 2002;36:367-75.
34. Smith DR, Leggat PA. Needlestick and sharps injuries among nursing students. J Adv Nurs. 2005;51:449-55.

35. Souza RT, Bica CG, Mondadori CS, Ranzi AD. Avaliação de acidentes de trabalho com materiais biológicos em médicos residentes, acadêmicos e estagiários de um hospital-escola de Porto Alegre. Rev Bras Educ Med. 2012;36:118-24.

36. Sullivan M, Masters O, Venkatesan P. Needlestick injuries amongst medical students in Birmingham, UK. J Hosp Infect. 2000;44:240-1.

37. Talas MS. Occupational exposure to blood and body fluids among Turkish nursing students during clinical practice training: frequency of needlestick/sharp injuries and hepatitis B immunisation. J Clin Nurs. 2009;18:1394-403.

38. Tarantola A, Abiteboul D, Rachline A. Infection risks following accidental exposure to blood or body fluids in health care workers: a review of pathogens transmitted in published cases. Am J Infect Control. 2006;34:367-75.

39. Trim JC, Elliott TSJ. A review of sharps injuries and preventative strategies. J Hosp Infect. 2003;53:237-42.

40. Tucker A, Phillips WR. Medical students and infection control: risks and precautions. Tokai J Exp Clin Med. 1999;24:169-76.

41. Unver V, Tastan S, Coskun H. The frequency and causes of occupational injuries among nursing students in Turkey. Arch Environ Occup Health. 2012;67:72-7.

42. Varma M, Mehta G. Needle stick injuries among medical students. J Indian Med Assoc. 2000;98:436-8

43. Varsou O, Lemon JS, Dick FD. Sharps injuries among medical students. Occup Med. 2009;59:509-11.

44. Wang H, Fennie K, He G, Burgess J, Williams AB. A training programme for prevention of occupational exposure to bloodborne pathogens: impact on knowledge, behaviour and incidence of needle stick injuries among student nurses in Changsha, People's Republic of China. J Adv Nurs. 2003;41:187-94.

45. Wicker S, Nurnberger F, Schulze JB, Rabenau HF. Needlestick injuries among German medical students: time to take a different approach? Med Educ. 2008;42:742-5.

46. Yamazhan T, Durusoy R, Tasbakan MI, Tokem Y, Pullukcu H, Sipahi OR, et al. Nursing students' immunisation status and knowledge about viral hepatitis in Turkey: a multi-centre cross-sectional study. Int Nurs Rev. 2011;58:181-5.

47. Yang YH, Wu MT, Ho CK, Chuang HY, Chen L, Yang CY, et al. Needlestick/sharps injuries among vocational school nursing students in southern Taiwan. Am J Infect Control. 2004;32:431-5.

48. Yao WX, Wu YL, Yang B, Zhang LY, Yao C, Huang CH, et al. Occupational safety training and education for needlestick injuries among nursing students in China: intervention study. Nurse Educ Today. 2013;33:834-7.

49. Zhang Z, Moji K, Cai G, Ikemoto J, Kuroiwa C. Risk of sharps exposure among health science students in northeast China. Biosci Trends. 2008:2:105-11.

Received: 27 January 2013

Accepted: 18 July 2013 